Article

\title{
Evaluation of the Possibility of Replacing Fly Ash with Glass Powder in Lower-Strength Concrete Mixes
}

\author{
Robert Jurczak $^{1, *(1)}$ and Filip Szmatuła ${ }^{2}$ \\ 1 Department of Road and Bridge Engineering, West Pomeranian University of Technology in Szczecin, \\ 70-310 Szczecin, Poland \\ 2 General Directorate for National Roads and Motorways, 70-340 Szczecin, Poland; fszmatula@gddkia.gov.pl \\ * Correspondence: robert.jurczak@zut.edu.pl
}

check for

updates

Citation: Jurczak, R.; Szmatuła, F.

Evaluation of the Possibility of Replacing Fly Ash with Glass Powder in Lower-Strength Concrete Mixes.

Appl. Sci. 2021, 11, 396. https://doi. org/10.3390/app11010396

Received: 1 December 2020 Accepted: 29 December 2020 Published: 4 January 2021

Publisher's Note: MDPI stays neutral with regard to jurisdictional clai$\mathrm{ms}$ in published maps and institutional affiliations.

Copyright: (C) 2021 by the authors. Licensee MDPI, Basel, Switzerland. This article is an open access article distributed under the terms and conditions of the Creative Commons Attribution (CC BY) license (https:// creativecommons.org/licenses/by/ $4.0 /)$.

\begin{abstract}
This article presents the results of research on the possibility of replacing fly ash with recycled waste glass in lower-strength concrete mixes. The results of testing concrete mixes containing either waste-glass powder or fly ash are presented in the article. A standard C12/15 concrete mix was chosen for the tests based on its common use for producing concrete for footings to support road kerbs and gutters along national roads in the Polish province of West Pomerania. In the first step of the testing procedure, reference mixes were prepared with $22.5 \%$ and $45 \%$ fly ash in relation to the content of cement. In the next step, mixes were prepared based on the same specification, except that glass powder was added in place of fly ash. The samples were then tested to determine the influence of waste-glass powder on the main properties of the prepared concrete mixes and on the performance of the concrete when hardened. All the samples were tested for 7 and 28-day compressive strength, water absorption, and freeze-thaw resistance in water. Next, the performance parameters of the samples containing waste-glass powder were compared to the reference mixes containing an equal amount of fly ash. The test results and their analysis allow us to conclude that mixes containing glass powder are not only equal to mixes containing fly ash, but even outperform them by a wide margin in terms of durability.
\end{abstract}

Keywords: waste-glass powder; fly ash; eco-efficient concrete; durability

\section{Introduction}

According to a communication issued by the European Commission in December 2019, decarbonisation of the energy sector is one of the priorities of the European Union (EU) and is of key importance to achieving the associated climate objectives for the years 2030 and 2050 [1]. To this end, it is necessary to switch from coal to renewable energy sources. Also, it needs to be remembered that concrete to which no waste materials have been added is rare nowadays. Some of these additions (e.g., fly ash) are well known and have been in common use for years. It is clear that the deficit of fly ash, due to the closure of coal-fired power plants, will restrict the availability of this long-used component in the future [1]. Hence, the need for further research to look for alternative waste materials is imperative. An analysis of concrete-mix designs containing low-strength concrete used for road construction in the Polish province of West Pomerania revealed that fly ash is a frequently used addition. The authors believe that it can be replaced with, for instance, recycled, ground waste glass. According to statistical data [2], the average glass-recycling rate in Poland in 2017 was as low as $62.5 \%$, compared to an average of $76.2 \%$ across the EU. Therefore, a large part of waste glass is still not being recycled. This means that the volume of waste glass being dumped into landfills increases annually by ca. half a million tonnes. It is also worth noting that reducing the impact of waste on the environment is of great importance in order to achieve the Green Deal goals. Depending on local conditions, after proper treatment (grinding), recycled waste glass, like fly ash, can be added to concrete at the production stage. This notably concerns waste glass that is unsuitable for recycling in 
glass factories due to excessive dirt or colour variety. Such waste glass can obviously be reused if it is first subject to preprocessing, i.e., primarily cleaning, separation of coloured from clear glass, and crushing to the appropriate particle size. However, this is not an easy task because of the complicated process of separating and sorting [3]. Figure 1 shows typical waste glass preprocessing and precleaning.

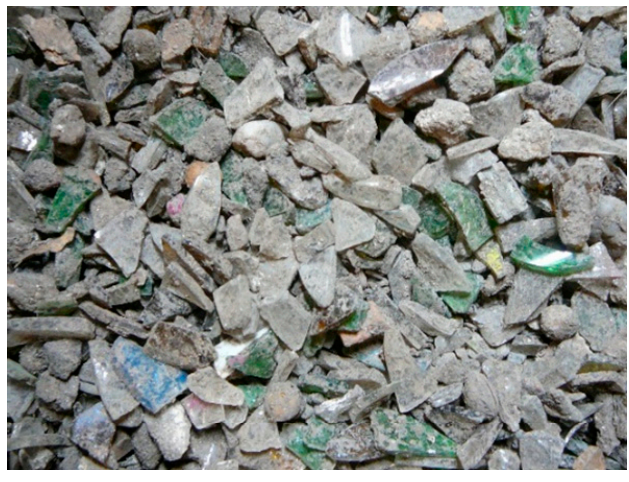

(a)

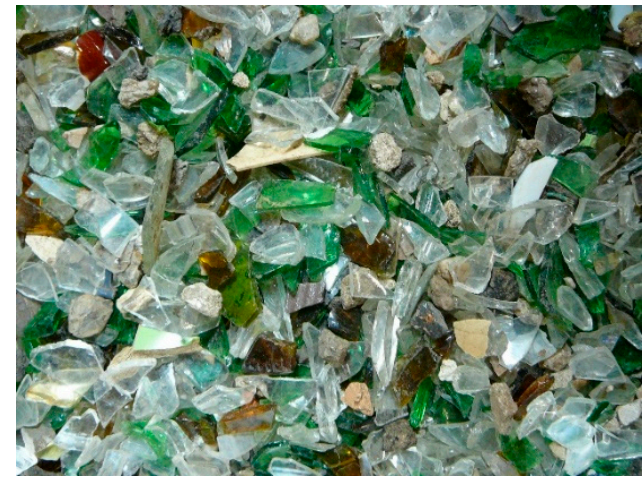

(b)

Figure 1. View of waste glass; raw (a) and precleaned (b).

Recent publications [4-13] indicate an increasing interest in waste glass and its application in concrete production. It is worth noting that use of glass as an addition to concrete can be limited due to the risk of alkali-silica reaction (ASR) [5-7,13]. Some studies have demonstrated that particles of glass greater than $1 \mathrm{~mm}$ make concrete more prone to ASR-induced damage $[7,8]$. Conversely, the addition of ground glass reduces or limits the adverse effect of expansive ASR products [13-15]. Other studies have demonstrated pozzolanic properties in concretes containing ground glass [14,16]. There are many research projects $[4,7,9,10,17]$ concerning concrete of $C 20 / 25$ strength class and higher, in which waste glass is most often seen as a partial substitute for cement, fine aggregate, or both of these ingredients at the same time. On the other hand, there are no studies treating waste glass in the same way as other concrete admixtures, i.e., as a filler and partial substitute for cement. While improving the performance of concrete, these additions can also reduce the amount of cement and lower the production cost. The research described in this article was inspired by the promising results of experiments conducted on concretes containing waste-glass powder, as presented in [18]. That being said, the authors have attempted to replace fly ash with recycled ground glass in low-strength-class mixes, i.e., up to C20/25. In road-construction applications, mixes of this type are used mainly for the casting of footings to support precast gutters laid along roads and kerbs. Currently, the only requirement for such mixes to be used on the national roads in Poland is that the concrete has a set minimum strength class. According to the requirements [19], such footings should be made from concrete with a compressive strength class of C12/15.

\section{Materials and Methods}

The subject of this research is the basic properties of concrete mixes and of hardened concrete with various additions. Two types of additions were used: siliceous fly ash (FA) and waste-glass powder (GP). The control mixes were produced with fly ash, which has been successfully used in concrete production for many years. From the observations made during quality control of works and materials used for the national roads in Poland, we knew that the content of fly ash in concretes can reach $50 \%$ by weight of cement (on the basis of the analysis of the specifications of C12/15 concrete used on national roads in the Polish province of West Pomerania). The amounts of fly ash added to the mix were $22.5 \%$ and $45 \%$ of the weight of cement (the percentage of cement remained unchanged). The design of the tested mixes was prepared on the basis of the control mix design, with 
fly ash being replaced by waste-glass powder. Therefore, a total of four series of concrete samples were prepared. The designations of the respective mixes indicate the type and the percentage content of the addition in relation to the weight of cement. The water to cement ratio $(\mathrm{W} / \mathrm{C}$ ) of 0.8 was constant in all the concrete mixes, and so was the grain size distribution. It was assumed that strength class C12/15 concrete, according to EN 206 [20], would be obtained after 28 days of curing. Concrete mixes were prepared using generalpurpose CEM I 42,5R Portland cement and natural aggregate, which was obtained by mixing washed sand with gravels of $2 / 8 \mathrm{~mm}$ and $8 / 16 \mathrm{~mm}$ grading. The mix specifications are given in Table 1 below.

Table 1. Mix specifications (the sources of the materials are given in parentheses).

\begin{tabular}{ccccc}
\hline \multirow{2}{*}{ Component (Amount per 1 $\left.\mathbf{~ m}^{\mathbf{3}} \mathbf{( k g )}\right)$} & \multicolumn{4}{c}{ Mix Symbol } \\
\cline { 2 - 5 } & C_FA_22.5 & C_FA_45.0 & C_GP_22.5 & C_GP_45.0 \\
\hline CEM I 42.5 R (Cemex) & 200 & 200 & 200 & 200 \\
Sand 0/2 (Bielinek) & 900 & 900 & 900 & 900 \\
Gravel 2/8 (Ognica) & 430 & 430 & 430 & 430 \\
Gravel 8/16 (Ognica) & 450 & 450 & 450 & 450 \\
Fly ash (Dolna Odra) & 45 & 90 & - & - \\
Waste-glass powder & - & - & 45 & 90 \\
Water & 160 & 160 & 160 & 160 \\
Water/cement ratio & 0.8 & 0.8 & 0.8 & 0.8 \\
\hline
\end{tabular}

The additions to concrete used in this research had different properties (Figure 2). Fly ash originated from coal combustion in the Dolna Odra power plant. Glass powder was obtained by crushing prebroken brown glass bottles in a laboratory crusher and grinding them in a Micro-Deval apparatus. The Blaine value of ground waste glass obtained in this way was $4737 \mathrm{~cm}^{2} / \mathrm{g}$, and the Blaine value of fly ash was $3983 \mathrm{~cm}^{2} / \mathrm{g}$. In this respect, fly ash is closer to cement $\left(3728 \mathrm{~cm}^{2} / \mathrm{g}\right)$. The highest density was obtained from cement $\left(3.10 \mathrm{~g} / \mathrm{cm}^{3}\right)$, and the lowest from fly ash $\left(2.00 \mathrm{~g} / \mathrm{cm}^{3}\right)$. The density of waste-glass powder was $2.52 \mathrm{~g} / \mathrm{cm}^{3}$. Fly ash and ground glass differ in terms of chemical composition. Brown glass powder contains more $\mathrm{SiO}_{2}$ (ca. $70 \%$ ) $[13,16,17]$ than fly ash (ca. 50\%) on average $[16,21]$.

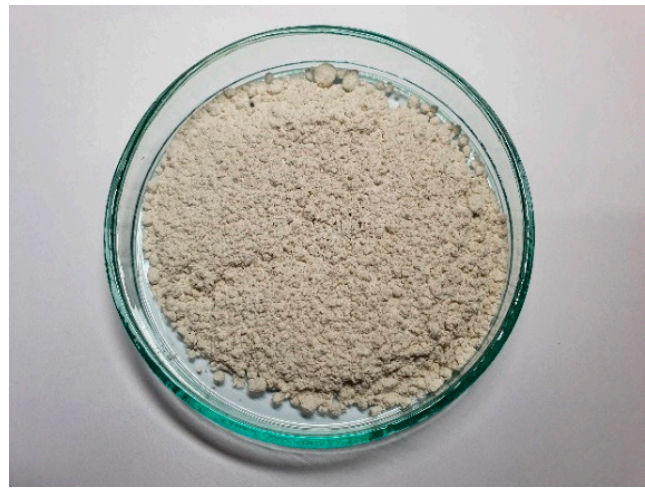

(a)

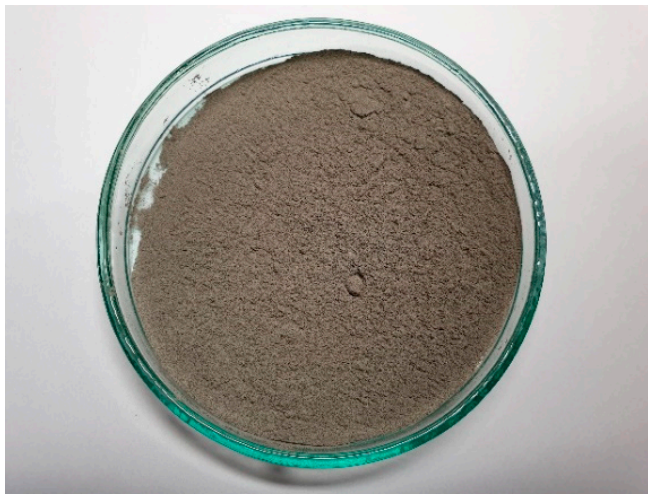

(b)

Figure 2. Waste-glass powder (a) and fly ash (b) used for producing the tested mixes.

The consistency of the produced concrete mixes was evaluated using the slump cone test according to EN 12350-2 [22], their density was measured according to EN 12350-6 [23], and the total air content was determined with the pressure gauge method according to EN 12350-7 [24], ten minutes after mixing the components. Samples for compressive strength 
testing according to EN 12390-3 [25] and for freeze-thaw durability testing according to PN-B-06250:1988 [26] were moulded in the next step.

A compressive strength test was performed in compliance with EN 12390-3 [25]. Six $150 \times 150 \times 150 \mathrm{~mm}$ concrete cubes were made from each test series. Before the tests, the density of the concrete was determined according to EN-12390-7 [27]. Since lowtemperature performance requirements were not specified for concrete used for the casting of footings under gutters and kerbs on national roads, the experiments were carried out as if they were used for freeze-thaw resistance classes F25 and F100. Freeze-thaw resistance was tested according to PN-B-06250:1988 [26], using the ordinary method. For dozens of years, this has been the main method used in Poland for rating the freeze-thaw resistance of concrete. Two sets of $100 \times 100 \times 100 \mathrm{~mm}$ cubes were prepared from each concrete series. Each set included 12 specimens, and 24 specimens were prepared from each mix; these were used to determine the freeze-thaw durability after 25 and 100 cycles, respectively. After demoulding, the specimens were cured by immersion in water at a temperature of $20 \pm 2{ }^{\circ} \mathrm{C}$. In the next step, the samples were weighed, and then six specimens of each mix were subjected to the predefined number of freeze-thaw cycles while the other six remained immersed in water. After cycling, all samples were reweighed and subjected to a compressive strength test, both those exposed to freezing and those left in water. A visual assessment of the samples was conducted prior to the test. Water absorption capacity by weight after 28 days of curing, according to PN-B-06250:1988 [26] and using the standard-sample $100 \times 100 \times 100 \mathrm{~mm}$ cubes, was also determined.

\section{Results and Discussion}

\subsection{Fresh Properties}

The test results obtained on the tested concrete mixes are given in Table 2 and Figure 3.

Table 2. Properties of the tested concrete mixes.

\begin{tabular}{cccccc}
\hline \multirow{2}{*}{ Parameter } & \multirow{2}{*}{ Unit } & \multicolumn{4}{c}{ Mix Symbol } \\
\cline { 3 - 6 } & & C_FA_22.5 & C_FA_45.0 & C_GP_22.5 & C_GP_45.0 \\
\hline Slump Cone & $\mathrm{mm}$ & 10 & 10 & 30 & 30 \\
Consistency class & - & $\mathrm{S} 1$ & $\mathrm{~S} 1$ & $\mathrm{~S} 1$ & $\mathrm{~S} 1$ \\
Density & $\mathrm{kg} / \mathrm{m}^{3}$ & 2280 & 2270 & 2250 & 2270 \\
Air content & $\%$ & 3.9 & 4.1 & 4.8 & 5.1 \\
\hline
\end{tabular}

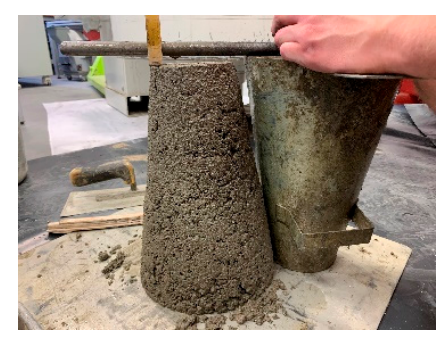

(a)

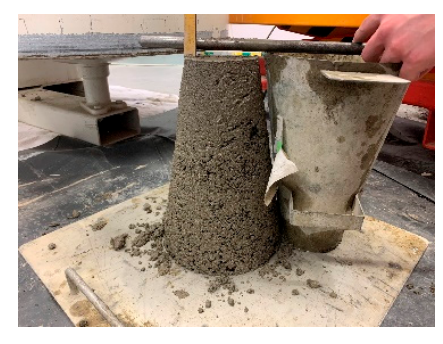

(b)

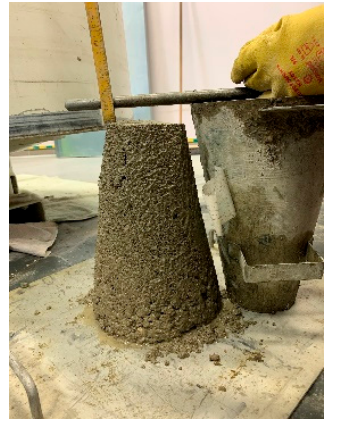

(c)

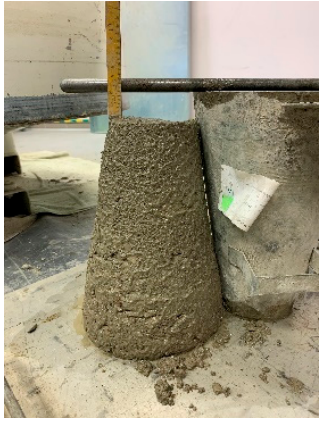

(d)

Figure 3. Slump cone test results: C_FA_22.5 (a), C_FA_45.0 (b), C_GP_22.5 (c) and C_GP_45.0 (d).

The tested concrete mixes gained the assumed initial consistency S1 (slump less than $50 \mathrm{~mm}$ ). The concrete mix with the addition of waste-glass powder was characterised by greater fluidity (greater slump) than the mix containing fly ash. This may be due to a lower water demand of glass and the smooth surface of glass particles. The amount of air was the 
highest in the mixes containing ground glass and the lowest in the mixes containing fly ash. Replacing fly ash with ground glass increased the total air content in the mix (by ca. 1\%).

\subsection{Hardened Properties}

\subsubsection{Compressive Strength}

The density of concrete samples oscillated between $2270 \mathrm{~kg} / \mathrm{m}^{3}$ and $2300 \mathrm{~kg} / \mathrm{m}^{3}$. The density of the tested mixes was in the range typical of regular concrete, namely $2000-2600 \mathrm{~kg} / \mathrm{m}^{3}$. Compressive strength was determined after 7 and 28 days of curing. Compressive strength was calculated based on the actual dimensions of the samples. The average values are represented in Figure 4. The minimum required compressive strength of C12/15 concrete is shown with a dashed line (19.0 MPa). The values obtained after 7 and 28 days of curing are represented by plain and crosshatched bars, respectively.

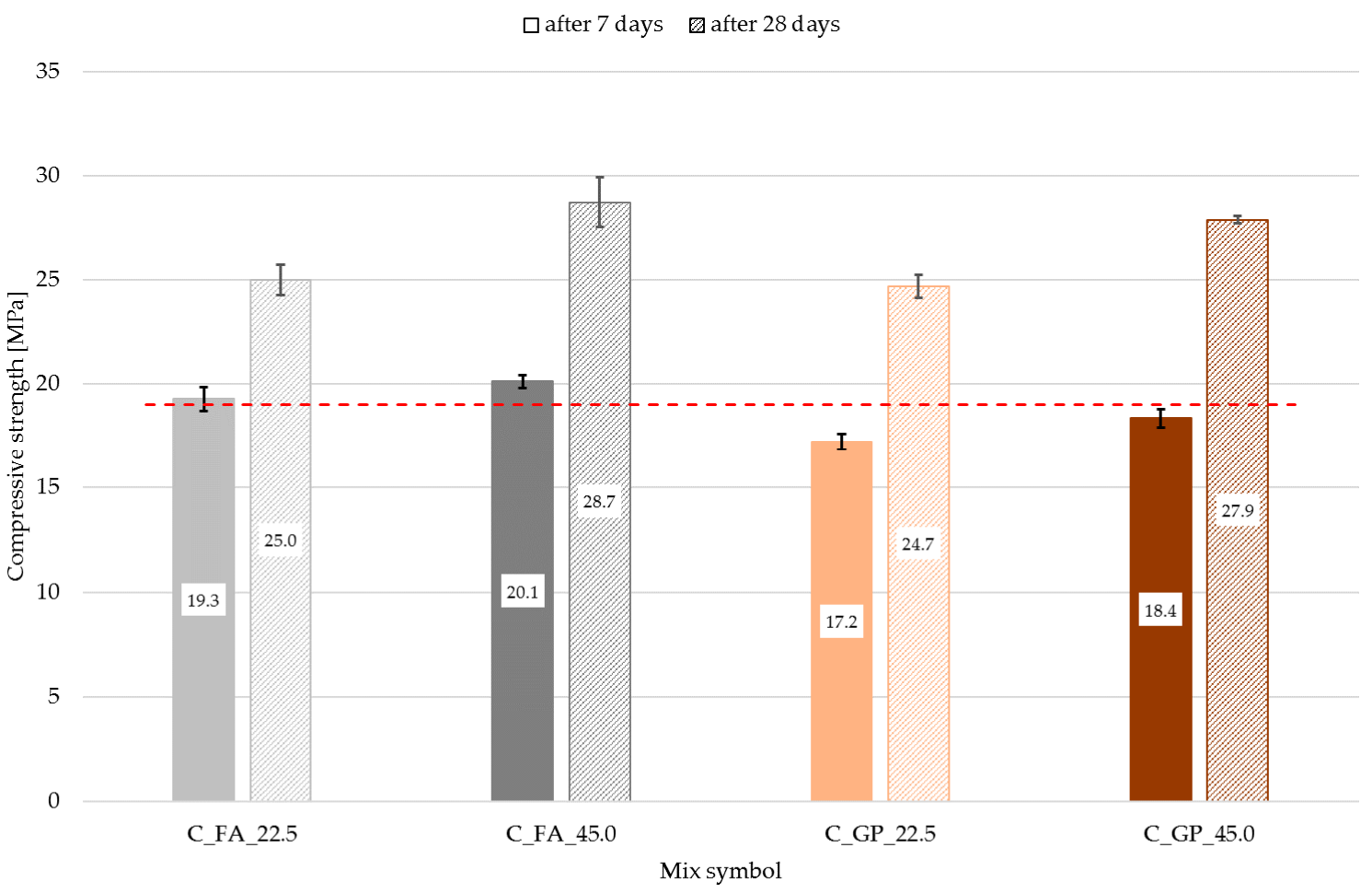

Figure 4. Compressive strength of the tested concrete mixes showing standard deviation.

After 28 days of curing, all the tested concrete mixes achieved the minimum compressive strength class. The mix containing fly ash obtained the highest compressive strength in all the tests. However, the range in compressive strength, compared to concrete with ground glass, of up to $2.9 \%$ was considered insignificant.

When comparing the compressive strength after 28 days and after 7 days of curing, we observed the greatest increase in the case of concrete with the addition of glass powder (by $43-52 \%$ depending on the quantity of glass added to the mix). For mixes with fly ash, compressive strength increased in this period by $30 \%$ to $40 \%$. The compressive strength increased with the quantity of additions.

\subsubsection{Water Absorption}

The water absorption of the tested mixes was determined in accordance with the Polish standard PN-B-06250:1988 [26]. Four specimens were prepared from each concrete series. The average values are represented in Figure 5. 


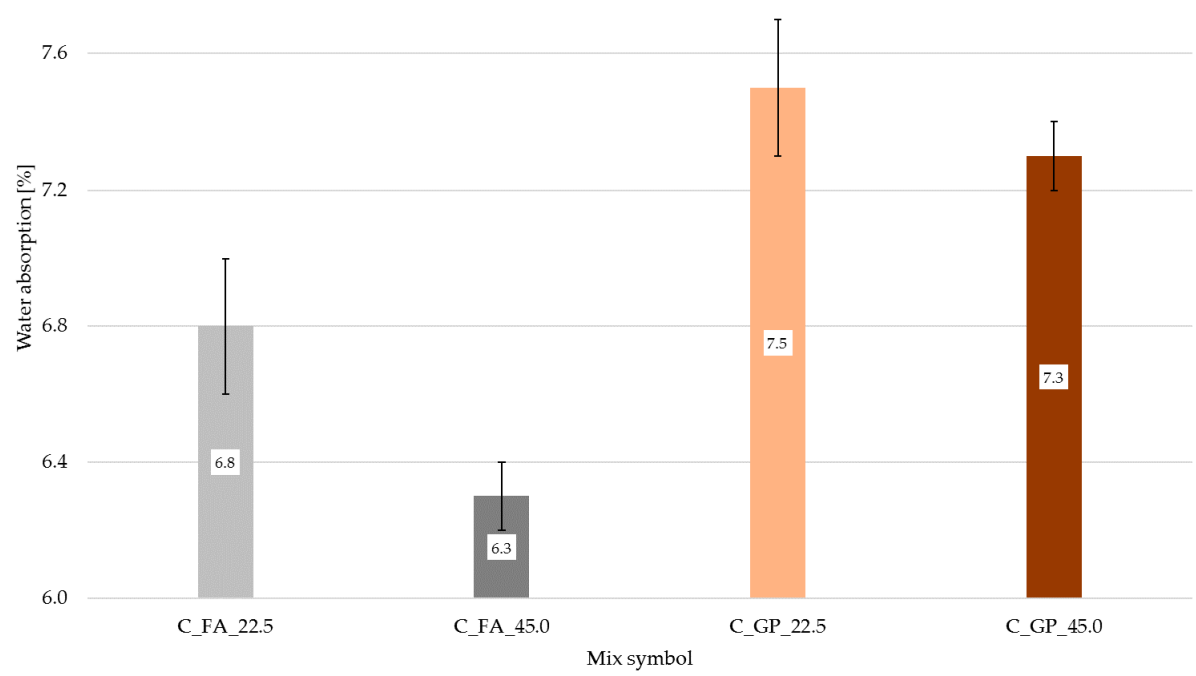

Figure 5. Water absorption of the tested mixes showing standard deviation.

Mixes containing fly ash showed the lowest water absorption of all the tested mixes after 28 days of curing. It was observed that the higher the fly-ash content in concrete, the lower its absorption capacity. The absorption values of mixes containing waste-glass powder were at a similar level of ca. $7.4 \%$.

\subsubsection{Freeze-Thaw Resistance}

According to the frost-resistance criteria of the Polish standard PN-B-06250:1988 [26], for concrete to be rated as "frost resistant", the weight variation $(\Delta \mathrm{G})$ must not exceed $5 \%$, the loss of compressive strength $(\Delta \mathrm{R})$ must not be higher than $20 \%$, and cracks must not occur during the test. The results of the durability tests (decrease in strength) of the mixes, including their resistance to freeze-thaw cycles for frost resistance of F25 and F100, are shown in the Figure 6. The dashed line indicates an average decrease of compressive strength of $20 \%$. The decrease of strength after 25 and 100 freeze-thaw cycles is represented by plain and crosshatched bars, respectively.

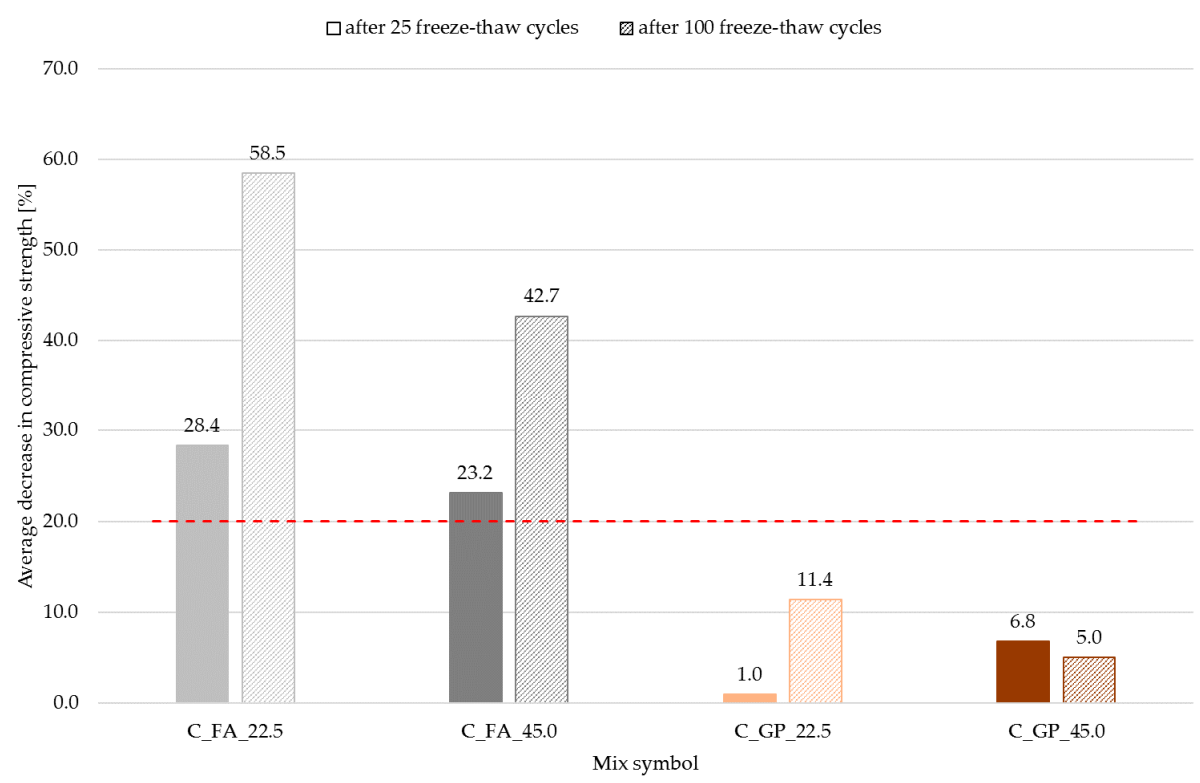

Figure 6. Decrease in compressive strength of mixes subjected to either 25 or 100 freeze-thaw cycles. 
An analysis of the results of the frost-resistance test revealed a big difference between the behaviour of concrete with fly ash and with glass powder when subjected to subzero temperatures. The effect of waste-glass powder on the durability of concrete after several freeze-thaw cycles was clearly noticeable. Based on the analysis of test results represented in Figure 6, it can be stated that only mixes with the addition of glass powder satisfied the requirements of either the F25 or F100 class, as per PN-B-06250:1988 [26]. The compressive strength of concrete with the addition of glass powder decreased by $1 \%$ to $11.4 \%$ on average, depending on the number of freeze-thaw cycles, which was far below the allowed limit of $20 \%$. The weight change did not exceed $0.1 \%$ (weight loss after 25 freeze-thaw cycles) and $0.2 \%$ (weight increase after 100 freeze-thaw cycles), which was less than the allowed limit of $\Delta G=5 \%$. Figure 6 shows that the average decrease in compressive strength after 28 days of curing (C_GP_45.0) was smaller than the average decrease in compressive strength after 7 days of curing. In the authors' opinion, considering the uncertainty of the measurements (expanded uncertainty of 3\%), this difference was not significant. The results for mixes containing fly ash admixture turned out to be diametrically different. Upon completion of freeze-thaw cycling, significant damage to the surface and edges of the samples was observed. One of every six specimens of fly-ash concrete mixes (C_FA_22.5) was destroyed in the tests (Figure 7a). An average decrease of compressive strength for these concretes exceeded the $20 \%$ value allowed by the norm [26] and, depending on the number of cycles applied, fell within a range between $23 \%$ and $59 \%$. The weight change did not exceed $0.6 \%$ (weight increase after 25 freeze-thaw cycles) and $1.5 \%$ (weight increase after 100 freeze-thaw cycles). Therefore, the tested concretes with the addition of fly ash should be considered nonresistant to frost action.

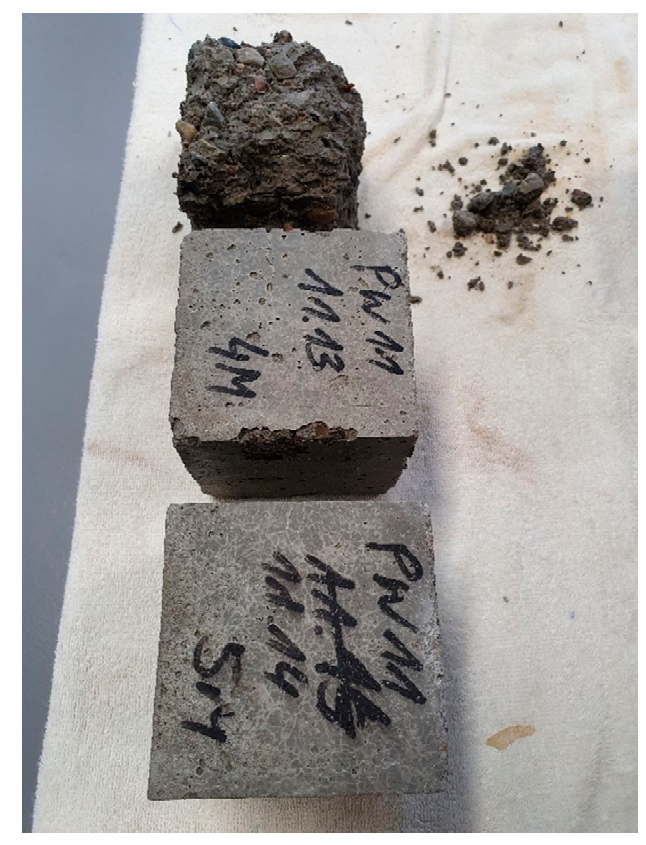

(a)

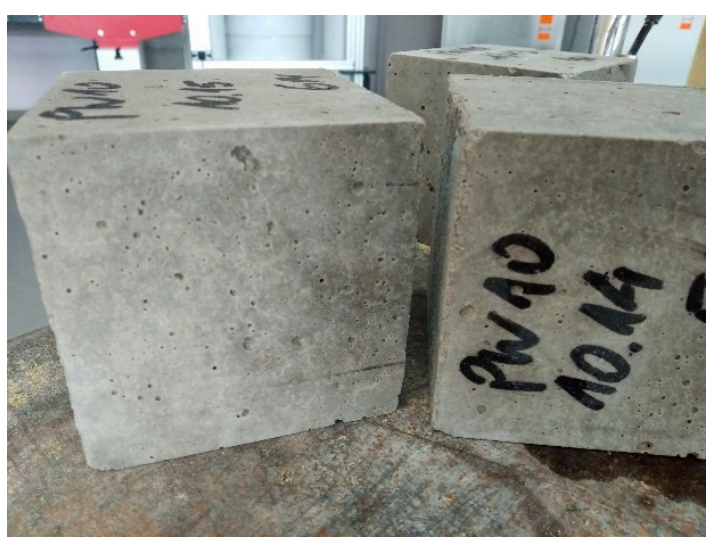

(b)

Figure 7. Specimens of concrete: C_FA_22.5 (a) and C_GP_22.5 (b) after 100 freeze-thaw cycles.

The greatest reduction in compressive strength (of $28 \%$ ) was observed for the mix containing $22.5 \%$ fly ash. In turn, the concrete containing $22.5 \%$ glass powder showed the smallest $(1 \%)$ change in compressive strength. Furthermore, compressive strength changed more significantly in the case of the concrete mixes subjected to a greater number of freeze-thaw cycles (100). Concrete with $45 \%$ fly ash was characterized by the greatest reduction of compressive strength (by $43 \%$ ) and concrete with $45 \%$ of glass powder showed the smallest reduction in compressive strength (of $5 \%$ ). 
The results were subjected to a statistical analysis in the Statistica software [28]. Strength calculations showed that the difference between the average compressive strengths (also referred to as the average decrease of compressive strength) between fly ash concrete and concrete containing glass powder was significant only in the case of the decrease of compressive strength in the freeze-thaw resistance test.

\subsubsection{Visual Assessment of Concrete Samples}

The pictures below shows the surfaces of the tested concrete samples after cutting (Figure 8).

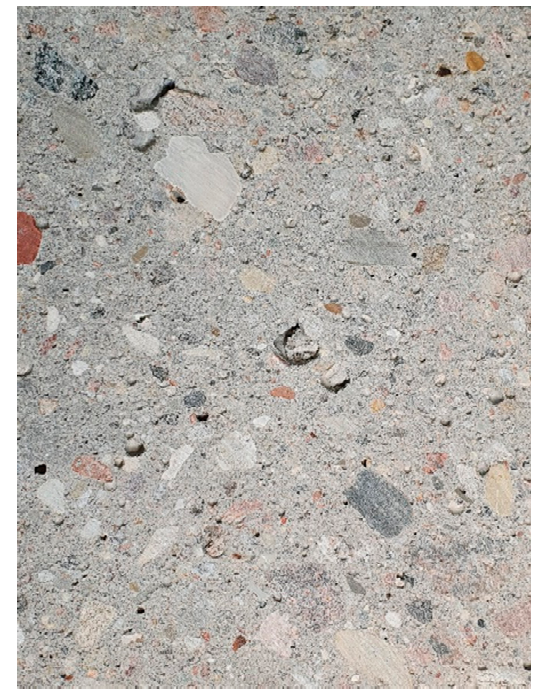

(a)

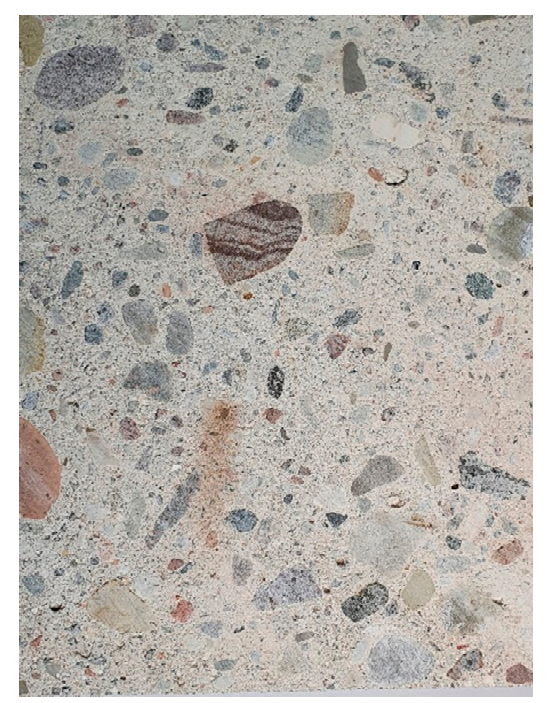

(c)

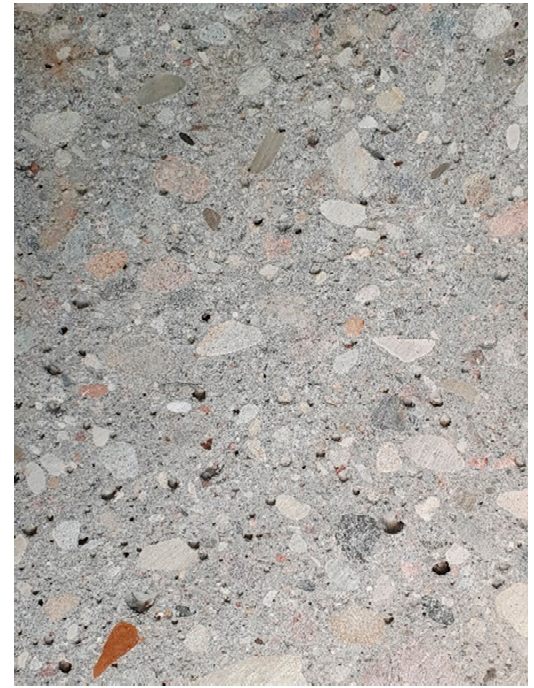

(b)

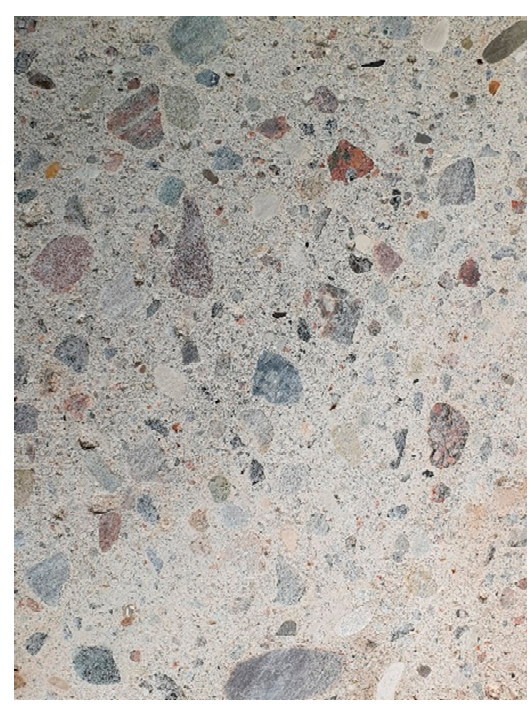

(d)

Figure 8. View of the concrete samples after cutting: C_FA_22.5 (a) C_FA_45.0, (b) C_GP_22.5, (c) and C_GP_45.0 (d).

Different microstructures were observed after cutting the concrete samples. On the surface of concrete samples with the addition of fly ash, a large number of pores with a diameter greater than $1 \mathrm{~mm}$ was noticed (Figure 8a,b). The analysis of the surface images of 
concrete samples showed that the structure of concrete with the addition of glass powder was more compact with lessened porosity (Figure 8c,d).

\section{Conclusions}

This article presents the results of experimental determinations of the properties of C12/15 concrete mixes and hardened concretes containing either fly ash or glass powder. Based on the performed research and analyses, the following can be concluded:

- Concrete mixes with glass powder are characterized by a greater liquidity and a greater total air content.

- Irrespective of the type and quantity of the added material, the concretes have comparable compressive strength classes falling in the range between 24.7 MPa and 28.7 MPa. All the tested mixes met the compressive strength requirements for $\mathrm{C} 12 / 15$ class concrete and can be used for casting footings to support road kerbs and gutters along national roads in Poland.

- The greatest differences between the mixes concerned durability. As a result of exposure to freezing temperatures, the control mixes with fly ash suffered considerable damage. Replacement of fly ash with waste-glass powder in C12/15 strength concrete result in concretes satisfying the freeze-thaw resistance criteria for classes F25 and F100.

In light of the test results obtained for the reference concretes (with fly ash addition), glass powder was shown to have no adverse effect on the compressive strength of concrete, did not significantly increase its water absorption, and significantly improved the resistance to frost attack. The above conclusions should be deemed preliminary and can be used as a basis for deriving a plan for further research. To begin with, the authors plan to verify ground waste glass added to concrete in terms of reactivity. Furthermore, for a more accurate picture, we also plan to carry out studies concerning the particle size and shape distribution of both fly ash and ground waste glass. Taking into consideration current efforts aimed at curbing $\mathrm{CO}_{2}$ emissions and material consumption, the results obtained in this study justify the need for further research on the use of recycled glass powder as a concrete admixture.

Author Contributions: Conceptualization, R.J. and F.S.; preparation of samples for testing, R.J. and F.S.; testing of samples concrete F.S.; formal analysis, R.J.; writing-original draft preparation, R.J.; writing-review and editing, R.J. and F.S. All authors have read and agreed to the published version of the manuscript.

Funding: This research received no external funding.

Institutional Review Board Statement: Not applicable.

Informed Consent Statement: Not applicable.

Data Availability Statement: Not applicable.

Conflicts of Interest: The authors declare no conflict of interest.

\section{References}

1. Communication from the European Commission. The European Green Deal. Available online: https://eur-lex.europa.eu/legalcontent/PL/TXT/HTML/?uri=CELEX:52019DC0640\&from=EN (accessed on 5 October 2020).

2. FEVE Recycling Statistics 2017. Available online: https:/ / feve.org/about-glass/statistics/ (accessed on 5 October 2020).

3. Sordoń-Kulibaba, B. Zagospodarowanie odpadów szkła i opakowań szklanych. Szkło Ceram. 2008, 59, $15-17$.

4. Rek, W.J.; Kopytko, M.; Opłocka, E. Wpływ stłuczki szklanej z recyklingu na wytrzymałość i trwałość betonu. Inżynieria Bud. 2019, 9, 429-434.

5. Małek, M.; Łasica, W.; Jackowski, M.; Kadela, M. Effect of Waste Glass Addition as a Replacement for Fine Aggregate on Properties of Mortar. Materials 2020, 13, 3189. [CrossRef] [PubMed]

6. Czapik, P. Microstructure and Degradation of Mortar Containing Waste Glass Aggregate as Evaluated by Various Microscopic Techniques. Materials 2020, 13, 2186. [CrossRef] [PubMed]

7. Sičáková, A.; Špak, M. The Effect of a High Amount of Micro-Fillers on the Long-Term Properties of Concrete. Materials 2019, 12, 3421. [CrossRef] [PubMed] 
8. Pavl, T. The Utilization of Recycled Materials for Concrete and Cement Production-A Review. IOP Conf. Ser. Mater. Sci. Eng. 2018, 442, 012014. [CrossRef]

9. Patel, D.; Tiwari, R.P.; Shrivastava, R.; Yadav, R.K. Effective utilization of waste glass powder as the substitution of cement in making paste and mortar. Constr. Build. Mater. 2019, 199, 406-415. [CrossRef]

10. Jain, K.L.; Sancheti, G.; Gupta, L.K. Durability performance of waste granite and glass powder added concrete. Constr. Build. Mater. 2020, 252, 119075. [CrossRef]

11. Skoczylas, K.; Rucińska, T. Influence of Grain Shape of Waste Glass Aggregate on the Properties of Cement Mortar. J. Ecol. Eng. 2020, 21, 148-159. [CrossRef]

12. Horszczaruk, E.; Brzozowski, P. Mechanical Properties of Mortars Containing Waste Glass Powder. Period. Polytech. Archit. 2019, 50, 30-34. [CrossRef]

13. Wang, Y.; Cao, Y.; Zhang, P.; Ma, Y. Effective utilization of Waste Glass as Cementitious Powder and Construction Sand in Mortar. Materials 2020, 13, 707. [CrossRef] [PubMed]

14. Deja, J.; Gołek, Ł.; Kołodziej, Ł. Zastosowanie stłuczki szklanej w produkcji spoiw. Cement Wapno Beton 2011, 6, 349-354.

15. Kamali, M.; Ghahremaninezhad, A. Effect of glass powders on the mechanical and durability properties of cementitious materials. Constr. Build. Mater. 2015, 98, 407-416. [CrossRef]

16. Gołek, Ł.; Kapeluszna, E. Zastosowanie stłuczki szklanej i popiołów fluidalnych do produkcji spoiw. Świat Szkła 2013, 5, 42-44.

17. Najduchowska, M.; Pabiś, E.; Rolka, G.; Baran, T. Właściwości betonu z zastosowaniem stłuczki szklanej. In Monografie Technologii Betonu, Proceedings of Dni Betonu, Wista, Polska, 10-12 October 2016; Stowarzyszenie Producentów Cementu: Kraków, Polska, 2016.

18. Jurczak, R.; Szmatuła, F.; Rudnicki, T.; Korentz, J. Effect of Ground Waste Glass Addition on the Strength and Durability of Low Strength Concrete Mixes. Materials 2021, 14, 190. [CrossRef]

19. Warunki Wykonania i Odbioru Robót Budowlanych. D-08.01.01 Krawężniki betonowe. GDDKiA. 2019. Available online: https://www.gddkia.gov.pl/frontend/web/userfiles/articles/d/dokumenty-techniczne_8162/WWiORB/punkt\%208/ D-08.01.01_KRAWEZŻNIKI\%20BETONOWE_V01.pdf (accessed on 5 October 2020).

20. EN 206:2014: Concrete_Part 1: Specification, Performance, Production and Conformity; CEN: Brussels, Belgium, 2014.

21. Łagosz, A.; Gajewski, R. Wpływ popiołu lotnego na trwałość betonu z cementami żużlowymi. Bud. Technol. Archit. $2008,1,60-65$.

22. EN 12350-2:2019: Testing Fresh Concrete_Part 2: Slump-test; CEN: Brussels, Belgium, 2019.

23. EN 12350-6:2019: Testing Fresh Concrete_Part 6: Density; CEN: Brussels, Belgium, 2019.

24. EN 12350-7:2019: Testing Fresh Concrete_Part 7: Air Content_Pressure Methods; CEN: Brussels, Belgium, 2019.

25. EN 12390-3:2019: Testing Hardened Concrete_Part 3: Compressive Strength of Test Specimens; CEN: Brussels, Belgium, 2019.

26. PN-B-06250:1988: Beton Zwykty; PKN: Warsaw, Poland, 1988.

27. EN 12390-7:2019: Testing hardened Concrete_Part 7: Density of Hardened Concrete; CEN: Brussels, Belgium, 2019.

28. TIBCO Software Inc. Statistica, Version 13; TIBCO Software Inc.: Palo Alto, CA, USA, 2017. 